\title{
Symptomatic cerebral oedema during treatment of diabetic ketoacidosis: effect of adjuvant octreotide infusion
}

\author{
Ora Seewi*, Anne Vierzig, Bernhard Roth, Eckhard Schönau
}

\begin{abstract}
Introduction: A potentially lethal complication of diabetic ketoacidosis (DKA) in children is brain oedema, whether caused by DKA itself or by the therapeutic infusion of insulin and fluids.

Case presentation: A 10-year old previously healthy boy with DKA became unconscious and apnoeic due to cerebral oedema (confirmed by abnormal EEG and CT-scan) during treatment with intravenous fluids ( $36 \mathrm{ml} / \mathrm{h})$ and insulin (0.1 units $/ \mathrm{kg} / \mathrm{h})$. He was intubated and artificially ventilated, without impact on EEG and CT-scan.

Subsequently, adjuvant infusion of octreotide was applied (3.5 $\mu \mathrm{g} / \mathrm{kg} / \mathrm{h})$, suppressing growth hormone (GH) and IGF-1 production and necessitating the insulin dose to be reduced to $0.05-0.025$ units $/ \mathrm{kg} / \mathrm{h}$. The brain oedema improved and the boy made a full recovery.

Conclusion: Co-therapy with octreotide was associated with a favourable outcome in the present patient with DKA and cerebral oedema. Whether this could be ascribed to the effects of octreotide on the insulin requirement or on the GH/IGF-axis remains to be elucidated.
\end{abstract}

\section{Introduction}

Cerebral oedema is the most feared complication of DKA. The pathogenesis appears complex and is poorly understood [1]. According to a recent working hypothesis, dehydration and hypocapnia diminish cerebral perfusion, resulting in mild brain ischaemia and subsequent cytotoxic and vasogenic cerebral oedema [1]. In this context, hypoxia-induced VEGF activity may play a role [2]. Insulin treatment might also contribute, for example via its sodium-retaining effects, or by its effects on the growth hormone $(\mathrm{GH})$ /insulin-like growth factor (IGF)axis [3]. Insulin increases serum IGF-1 and decreases IGFBP-1, thereby increasing free IGF-1 activity. IGF-1 increases capillary permeability [4] and oedema formation $[5,6]$, probably via increasing the activity of VEGF $[7,8]$. As insulin enters the brain [9], these effects may on a local level-contribute to cerebral oedema during DKA. Somatostatin, which counteracts some insulin effects on the GH/IGF-axis [10] and lowers free IGF-1 in particular [11], was successfully applied in complicated

\footnotetext{
* Correspondence: ora.seewi@uk-koeln.de

Uniklinik Köln, Clinic for General Paediatrics, University Hospital of Cologne, Germany
}

DKA by Bosnak et al. [12]. These authors added a somatostatin infusion to the standard DKA therapy in two unconscious children with DKA who subsequently regained consciousness within 3-4 hours. The therapeutic mechanism of somatostatin in this condition remains obscure. We provide additional evidence for the use of somatostatin to improve the outcome of cerebral oedema in childhood DKA.

\section{Case presentation}

A previously healthy boy of 10 years (estimated body weight $25 \mathrm{~kg}$ ) was admitted acutely after vomiting for 8 hours, preceded by polyuria, polydipsia, weight loss and malaise for 3 days. He was conscious, but drowsy (Glasgow Coma Scale score 12). A diagnosis of diabetic ketoacidosis was made because of hyperglycaemia $(1329 \mathrm{mg} / \mathrm{dl})$ and metabolic acidosis $(\mathrm{pH} \mathrm{7.07,} \mathrm{base}$ excess-19.7 mmol/l). He was severely dehydrated and displayed Kussmaul breathing. Immediately upon admission he received a s.c. injection of 2.5 units of regular human insulin, followed by continuous intravenous infusion of regular insulin at a dose of $0.1 \mathrm{U} / \mathrm{kg} / \mathrm{h}$. Simultaneously, an intravenous bolus infusion of $250 \mathrm{ml}$ of 
0.6\% saline was administered, followed by continuous intravenous infusion of $0.9 \%$ saline and $0.45 \% \mathrm{NaCl}$ plus $5 \%$ glucose $(36 \mathrm{ml} / \mathrm{h})$. The baseline blood chemistry showed pre-renal kidney failure (serum creatinine 3.75 $\mathrm{mg} / \mathrm{dl}$, urea $151 \mathrm{mg} / \mathrm{dl}$, uric acid $20.4 \mathrm{mg} / \mathrm{dl}$ ), circulatory insufficiency (lactate $3.2 \mathrm{mmol} / \mathrm{l}$ ) and dehydration (measured osmolality $444 \mathrm{mosmol} / \mathrm{kg}$, haematocrit $54 \%$ ). Furthermore, leukocytosis $(15.77 \times 10-9 / 1)$ and a reduced serum chloride of $88 \mathrm{mmol} / \mathrm{l}$ were noted. The serum sodium, potassium, phosphate, calcium, magnesium, CRP, liver enzymes and clotting factors were normal. The serum GH was elevated $(7.5 \mathrm{ng} / \mathrm{ml})$, while the IGF1 was below the detection limit $(<10 \mathrm{ng} / \mathrm{ml})$, consistent with acquired $\mathrm{GH}$ insensitivity. After 10 hours of treatment with insulin and potassium-supplemented fluids, the acidosis had almost been cured $(\mathrm{pH} 7.39$, base excess $-2.8 \mathrm{mmol} / \mathrm{l})$, and glycaemia was more than halved $(549 \mathrm{mg} / \mathrm{dl})$. The serum osmolality had dropped to $380 \mathrm{mosmol} / \mathrm{l}$, the $\mathrm{GH}$ had fallen to $2 \mathrm{ng} / \mathrm{ml}$, and the IGF-1 had risen to $23 \mathrm{ng} / \mathrm{ml}$ (suggestive of an immediate, insulin-induced rise in circulating IGF-1 $[13,14])$. See Table 1 for a summary of the laboratory data.

However, the boy became agitated and febrile and exhibited apnoeic phases indicative of incipient cerebral

Table 1 Laboratory data before, during and after treatment of DKA

\begin{tabular}{lcccc}
\hline Blood chemistry & \multicolumn{4}{c}{ Time (h) after admission } \\
\hline & 0 & 10 & 24 & 44 \\
Glucose $(\mathrm{mg} / \mathrm{dl})$ & 1392 & 549 & 214 & 114 \\
$\mathrm{PH}$ & 7.07 & 7.39 & 7.33 & 7.35 \\
$\mathrm{HCO}_{3}(\mathrm{mmol} / \mathrm{l})$ & 9.2 & 22.5 & 20.3 & 21.7 \\
Base excess (mmol/l) & -19.7 & -2.8 & -4.9 & -3.1 \\
$\mathrm{Na}+(\mathrm{mmol} / \mathrm{l})$ & 143 & 162 & 154 & 158 \\
$\mathrm{~K}+(\mathrm{mmol} / \mathrm{l})$ & 5.8 & 4.9 & 5.6 & 3.5 \\
Osmolality $(\mathrm{mosmol} / \mathrm{kg})$ & 444 & 380 & $\mathrm{n} . \mathrm{a}^{*}$ & 342 \\
Creatinine (mg/dl) & 3.75 & 1.86 & 1.66 & 1.24 \\
Haematocrit $(\%)$ & 54 & 45 & 44 & 40 \\
Lactate $(\mathrm{mmol} / \mathrm{l})$ & 3.2 & 1.5 & 1.3 & 1.1 \\
GH (ng/ml) & 7.5 & n.a* & 2.0 & $<0.16$ \\
IGF-1 (ng/ml) & $<10$ & n.a* & 23 & $<10$ \\
\hline
\end{tabular}

*not analysed

Reference values for a 10 year old male child

Fasting blood glucose: $60-110 \mathrm{mg} / \mathrm{dl}$;

arterial $\mathrm{pH}$ 7.4;

arterial HCO3 $31 \mathrm{mmol} /$;

arterial base excess $+5 \mathrm{mmol} / \mathrm{l}$;

arterial serum lactate $1.0-1.6 \mathrm{mmol} / \mathrm{l}$;

venous serum natrium $130-145 \mathrm{mmol} / \mathrm{l}$;

venous serum potassium 3.2-5.4 mmol//;

venous serum osmolality $280-296 \mathrm{mosmol} / \mathrm{kg}$;

venous serum creatinine $<0.9 \mathrm{mg} / \mathrm{dl}$;

venous blood haematocrit $34-46 \%$;

venous serum random $\mathrm{GH}<4 \mathrm{ng} / \mathrm{ml}$;

venous serum IGF-1: $159-300 \mathrm{ng} / \mathrm{ml}$. oedema. He was intubated and artificially ventilated under sedation with propofol and later midazolam, ketamin and fentanyl. Repeated CT-scans of the brain were unhelpful (in retrospect, the intercaudate diameter was narrowed by $4.8 \mathrm{~mm}$ (see Fig 1a)). Electroencephalography (EEG), however, showed a slow basic rhythm consistent with the manifestation of encephalopathy. At this point, DKA treatment failure was considered and it was, therefore, decided to try infusion of the somatostatinanalogue octreotide $(3.5 \mu \mathrm{g} / \mathrm{kg} / \mathrm{h})$, according to Bosnak et al. [12]. In response to the octreotide infusion, the insulin requirement decreased while serum $\mathrm{GH}$ and IGF-1 decreased below the detection limits, and serum osmolality decreased to $342 \mathrm{mosmol} / \mathrm{l}$. After 20 hours of co-therapy with octreotide, extubation was successfully attempted. The octreotide infusion was tapered off and

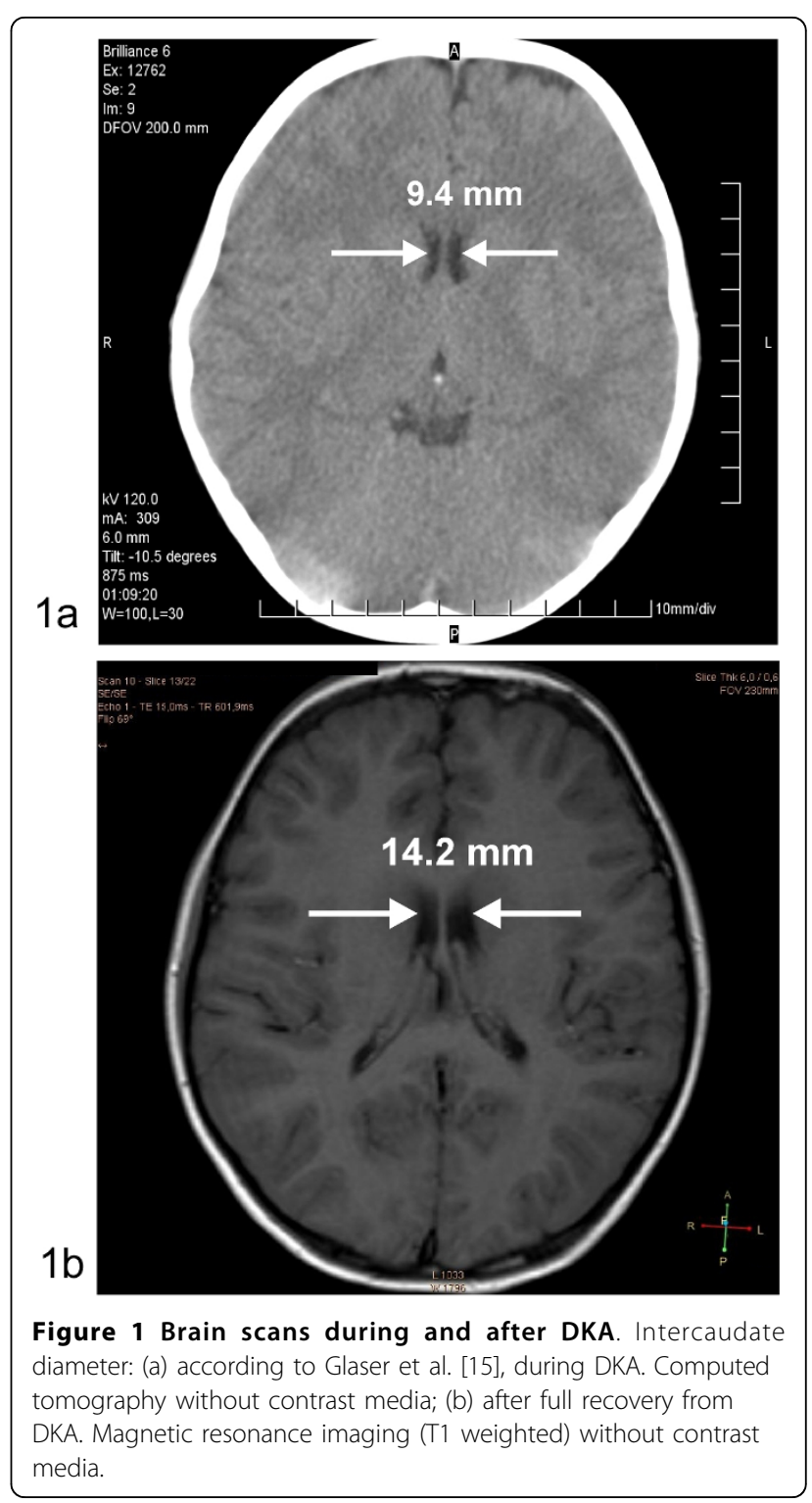


Table 2 Treatment items before, during and after treatment of DKA

\begin{tabular}{|c|c|c|c|c|}
\hline \multirow[t]{2}{*}{ Treatment items } & \multicolumn{4}{|c|}{ Time (h) after admission } \\
\hline & 0 & 10 & 24 & 44 \\
\hline net fluid gain* $(\mathrm{ml} / \mathrm{kg})$ & 10 & 13 & 83 & 116 \\
\hline GCS**score $(3-15)$ & 12 & 8 & not applicable & 15 \\
\hline $\begin{array}{l}\text { Artificial ventilation } \\
-/+\end{array}$ & - & $-<++++$ & ++++++++++ & $++++>-$ \\
\hline $\begin{array}{l}\text { Octreotide infusion } \\
(\mu \mathrm{g} / \mathrm{kg} / \mathrm{h})\end{array}$ & 0 & 0 & 3.5 & 1.8 \\
\hline $\begin{array}{l}\text { Insulin infusion } \\
(\mathrm{U} / \mathrm{kg} / \mathrm{h})\end{array}$ & 0.1 & 0.1 & 0.05 & 0.025 \\
\hline
\end{tabular}

the insulin infusion was changed to subcutaneous injections. The patient made a full recovery without neurological deficits. The treatment is summarized in Table 2.

The transient increases in liver enzymes had normalized at the time of discharge, as had all of the other laboratory abnormalities, except for an HbA1c of $12 \%$ (normal 4-6\%). The fasting serum GH was $0.16 \mathrm{ng} / \mathrm{ml}$ and the IGF-1 was $132 \mathrm{ng} / \mathrm{ml}$, suggesting normalized GH sensitivity. The patient was discharged with $23 \mathrm{U}$ of $\mathrm{NPH}$, and $20 \mathrm{U}$ of regular human insulin per day. One week after discharge, the intercaudate diameter was no longer narrowed on cranial MRI (Fig. 1b).

\section{Discussion}

The case of our patient is comparable to those reported by Bosnak et al. [12], in that a comatose child with DKA receiving co-therapy with the somatostatin analogue octreotide regained consciousness. However, the patients of Bosnak et al. were already unconscious before the onset of treatment, and it was claimed that they did not have brain oedema [12]. By contrast, our patient lost consciousness during insulin and fluid substitution and subsequently developed cerebral oedema (according to the established criteria [15], see Fig. 1a, b).

Fluid overload, the use of sodium bicarbonate or prolonged acidosis are unlikely to have caused cerebral oedema in our patient as sodium bicarbonate administration had been withheld and the net fluid gain was only $326 \mathrm{ml}(13 \mathrm{ml} / \mathrm{kg})$ during the first 10 hours, and the acidosis was almost cured when cerebral oedema occurred. However, hyperosmolality had dropped considerably (from 444 to $380 \mathrm{mosmol} / \mathrm{l}$ ) at that time point, probably because $0.6 \%$ rather than $0.9 \%$ saline was given without consideration of the current guidelines $[15,16]$. This might have contributed to the development of brain oedema, although consciousness was regained later despite a further drop in osmolality (from 380 to 342 mosmol/l). Thus, additional factors deserve consideration, for example insulin [17] and its effects on IGF-1.

In insulin-naive untreated type- 1 diabetic children with DKA, serum insulin concentrations are $<5 \mu \mathrm{U} / \mathrm{ml}$ (unpublished observation) and increase upon therapeutic intravenous insulin infusion at a rate of $0.1 \mathrm{U} / \mathrm{kg} / \mathrm{h}$ to approximately $60-100 \mu \mathrm{U} / \mathrm{ml}[13,18-20]$. Such serum insulin levels could also have been assumed in our patient at the time of developing brain oedema (unfortunately the insulin levels were not measured). Continuous hyperinsulinaemia such as this overcomes insulin resistance, shuts off glycolysis, gluconeogenesis and ketogenesis, half-maximally increases glucose uptake[20], and furthermore substantially increases circulating IGF-1 within a few hours $[13,14]$. A rapid increase in circulating IGF-1 from below the normal range to the upper normal range [13,14] may contribute to the formation of oedema in general, and to cerebral oedema during DKA treatment, which is consistent with previous reports [4-6].

During co-therapy with octreotide, the insulin infusion rate had to be reduced from $0.1 \mathrm{U} / \mathrm{kg} / \mathrm{h}$ to $0.05 \mathrm{U} / \mathrm{kg} / \mathrm{h}$ (as with the patients of Bosnak et al.), probably due to the inhibition of glucagon and GH secretions. An insulin infusion rate this low is associated with a serum insulin concentration of $10-15 \mu \mathrm{U} / \mathrm{ml}$, and avoidance of the immediate upregulation of serum IGF-1 during DKA treatment (unpublished observation). Contrary to current guidelines $[16,21]$ it was recently shown that low rate insulin infusion may be particularly safe in DKA $[17,22]$.

In our patient, octreotide completely inhibited the insulin-induced surge of circulating IGF-1, most likely through the inhibition of GH secretion. Moreover, octreotide must have affected the serum IGFBP-1 and free IGF-1 in our patient (not measured). In severe insulin deficiency, for example in diabetic ketoacidosis, IGFBP-1 is upregulated while hepatic IGF-1 secretion is reduced, despite increased $\mathrm{GH}[2,13,14,23]$. Insulin substitution reverses these abnormalities [2]. By contrast, octreotide administration increases circulating IGFBP-1 $[10,11]$ and thereby reduces free IGF-1 [11]; moreover, it antagonizes the stimulating effect of GH on IGF-1 generation in various tissues, e.g. the brain. Both processes may have contributed to the resolution of cerebral oedema in our patient, and to the regaining of consciousness in the patients of Bosnak et al., as resolution of diabetic macula oedema was observed in response to octreotide administration $[24,25]$.

In summary, we report for the first time a successful adjunctive therapy with octreotide in a patient with DKA and proven cerebral oedema. Although we cannot prove a cause-effect relationship, we believe that the potential of octreotide in this condition warrants further study.

\section{Abbreviations}

CT: computed tomography; DKA: diabetic ketoacidosis; GH: growth hormone; IGF-1: insulin-like growth factor 1; IGFBP-1: insulin-like growth 
factor binding protein 1; MRI: magnetic resonance imaging; VEGF: vascular endothelial growth factor

\section{Consent}

Written consent was obtained from the patient's parents for publication of this case report and any accompanying images. A copy of the written consent is available for review by the Editor-in-Chief of this journal.

\section{Competing interests}

The authors declare that they have no competing interests.

\section{Authors' contributions}

OS analyzed and interpreted the patient data and was major contributor in writing the manuscript. AV and BR were responsible for the intensive care of the patient. ES was involved in drafting the paper. All authors read and approved the final manuscript.

Received: 2 May 2010 Accepted: 19 August 2010

Published: 19 August 2010

\section{References}

1. Glaser N: New perspectives on the pathogenesis of cerebral edema complicating diabetic ketoacidosis in children. Pediatr Endocrinol Rev 2006, 3:379-386.

2. Schoch HJ, Fischer S, Marti HH: Hypoxia-induced vascular endothelial growth factor expression causes vascular leakage in the brain. Brain 2002, 125:2549-2557.

3. Bereket A, Lang HC, Wilson TA: Alterations in the growth hormoneinsulin-like growth factor axis in insulin dependent diabetes mellitus. Horm Metab Res 1999, 31:172-181.

4. Hussain MA, Studer K, Messmer EP, Froesch ER: Treatment with insulin-like growth factor I alters capillary permeability in skin and retina. Diabetes 1995, 44:1209-1212.

5. Lee PD, Pivarnik JM, Bukar JG, Muurahainen N, Berry PS, Skolnik PR, Nerad JL, Kudsk KA, Jackson L, Ellis KJ, Gesundheit N: A randomized, placebo-controlled trial of combined insulin-like growth factor I and low dose growth hormone therapy for wasting associated with human immunodeficiency virus infection. J Clin Endocrinol Metab 1996, 81:2968-2975.

6. Thrailkill KM, Quattrin T, Baker L, Kuntze JE, Compton PG, Martha PM, rhIGF-I in IDDM Study Group: Cotherapy with recombinant human insulin-like growth factor I and insulin improves glycemic control in type 1 diabetes. Diabetes Care 1999, 22:585-592.

7. Poulaki V, Quin W, Joussen AM, et al: Acute intensive insulin therapy exacerbates diabetic blood-retinal barrier breakdown via hypoxiainducible factor alpha and VEGF. J Clin Invest 2002, 109:805-815.

8. Zhang C, Hao L, Wang L, Xiao Y, Ge H, Zhu Z, Luo Y, Zhang Y, Zhang Y: Elevated IGFIR expression regulating VEGF and VEGF-C predicts lymph node metastasis in human colorectal cancer. BMC Cancer 2010, 10:184.

9. Laron Z: Insulin and the brain. Arch Physiol Biochem 2009, 115:112-116.

10. Ezzat $S$, Ren SG, Braunstein GD, Melmed S: Octreotide stimulates insulinlike growth factor-binding protein-1: a potential pituitary-independent mechanism for drug action. J Clin Endocrinol Metab 1992, 75:1459-1463.

11. Pokrajac A, Frystyk J, Flyvbjerg A, Trainer P: Pituitary-independent effect of octreotide on IGF-1 generation. Eur J Endocrinol 2009, 160:543-548.

12. Bosnak M, Dikici B, Dogru O, Davutoglu M, Haspolat K: Somatostatin therapy in the management of resistant diabetic ketoacidosis. Letter. Diabetes Care 2002, 25:629-630.

13. Glaser EW, Goldstein S, Phillips LS: Nutrition and somatomedin. XVII. Circulating somatomedin $C$ during treatment of diabetic ketoacidosis. Diabetes 1987, 36:1152-1160.

14. Bereket A, Lang $\mathrm{CH}$, Blethen SL, Gelato MC, Fan J, Frost RA, Wilson TA Effect of insulin on the IGF system in children with new onset insulin dependent diabetes mellitus. J Clin Endocrinol Metab 1995, 80:1312-1317.

15. Glaser NS, Wooton-Gorges SL, Buonocore MH, Marcin JP, Rewers A, Strain J, DiCarlo J, Neely EK, Barnes P, Kuppermann N: Frequency of sub-clinical cerebral edema in children with diabetic ketoacidosis. Pediatric Diabetes 2006, 2:75-80.

16. Wolfsdorf J, Craig ME, Daneman D, Dunger D, Edge J, Lee WR, Rosenbloom A, Sperling MA, Hanas R, International Society for Pediatric and Adolescent Diabetes: Diabetic ketoacidosis. Pediatr Diabetes 2007, 8:28-43.
17. Edge JA, Jakes RW, Roy Y, Hawkins M, Winter D, Ford-Adams ME, Murphy NP, Bergomi A, Widmer B, Dunger DB: The UK case-control study of cerebral edema complicating diabetic ketoacidosis in children. Diabetologia 2006, 49:2002-2009.

18. Martin MM, Martin ALA: Continuous low-dose infusion in the treatment of diabetic ketoacidosis in children. J Pediatr 1976, 89:560-564.

19. Shichiri M, Kawamori R, Murata T, Yamasaki Y, Morishima T, Abe H: Quantification of insulin resistance and adaptive blood glucose control in diabetic ketosis and ketoacidosis by the artificial endocrine pancreas with computer algorithm for self-adaptive control. Horm Metab Res/ Supplement Series 1982, 12:212-215.

20. Schade DS, Eaton RP: Dose response to insulin in man: differential effects on glucose and ketone body regulation. J Endocrinol Metab 1977, 44:1038-1053.

21. Datz N, Schuetz W, Kordonouri O, Nestoris C, Hethey S, Engelcke G, Danne T: Cerebral crisis in severe diabetic ketoacidosis (DKA) despite adaequate fluid and insulin therapy. Abstract. Pediatric Diabetes 2009, 10(Suppl 11):34

22. Putta R, Cooke D, Subbarayan A, Odeka E, Ariyaswansa I, Bine M, Doughty I, Patel L, Amin R, North West England Paediatric Diabetes Network: Low dose $(0.05$ units $/ \mathrm{kg} / \mathrm{h})$ is comparable with standard dose $(0.1 \mathrm{units} / \mathrm{kg} / \mathrm{h})$ intravenous insulin infusion for the initial treatment of diabetic ketoacidosis in children with type 1 diabetes - an observational study. Pediatric Diabetes 2010, 11:12-17.

23. Khan ASA, Siddals KW, Gardener EA, Kaushal K, Tieszen KL, New JP, Gibson JM: Marked changes in insulin-like growth factor (IGF) system and the phosphorylation of insulin-like growth factor binding protein-1 (IGFBP-1) during recovery from diabetic ketoacidosis (DKA). Abstract. Diabetologia 2003, 46(Suppl 2):A 242.

24. Grant MB, Caballero S: The potential role of octreotide in the treatment of diabetic retinopathy. Treat Endocrinol 2005, 4:199-203.

25. Chantelau E, Frystyk J: Progression of diabetic retinopathy during improved metabolic control may be treated with reduced insulin dosage and/or somatostatin analogue administration - a case report. Growth Hormone \& IGF Research 2005, 15:130-135.

doi:10.1186/1758-5996-2-56

Cite this article as: Seewi et al: Symptomatic cerebral oedema during treatment of diabetic ketoacidosis: effect of adjuvant octreotide infusion. Diabetology \& Metabolic Syndrome 2010 2:56.

\section{Submit your next manuscript to BioMed Central and take full advantage of:}

- Convenient online submission

- Thorough peer review

- No space constraints or color figure charges

- Immediate publication on acceptance

- Inclusion in PubMed, CAS, Scopus and Google Scholar

- Research which is freely available for redistribution

Submit your manuscript at www.biomedcentral com/submit
C Biomed Central 